\title{
Actual issues of digitalization in the industrial sector of the economy of Uzbekistan
}

\section{Konstantin KURPAYANIDI ${ }^{1}$}

Fergana Polytechnic Institute

\begin{tabular}{l} 
ARTICLE INFO \\
\hline Article history: \\
Received March 2021 \\
Received in revised form \\
20 March 2021 \\
Accepted 15 April 2021 \\
Available online \\
20 May 2021 \\
\hline
\end{tabular}

\section{Keywords:}

industrial sector, innovations, innovation process, competitive environment, digital economy, digitalization.

\section{ABSTRACT}

The article is devoted to disclosing the essence of digital transformation of industry, which, according to the author, is the key to building a knowledge of economy and obtaining measurable economic results through the introduction of end-toend technologies. The digitalization process of industry plays an important role in the technological development of regional spatial and sectoral structures, therefore, the production of hightech products by industry based on innovative digital technologies is of key importance for the development of the country's economy. The author conducted a systematic analysis of the problems of digitalization of the industrial sector of the national economy of Uzbekistan. The article proves the effectiveness of digitalization on the example of successfully functioning companies. It is substantiated that the digital transformation of production should be aimed at increasing the efficiency, productivity and competitiveness of the domestic industry in the world market.

The study concludes that it is necessary to actively implement digital economy tools in the industrial sector.

The results of research can be used to develop digitalization processes in the industrial sector of the economy of Uzbekistan and to increase their focus on the growth of competitive advantages and technological progress of regional spatial and sectoral structures in the conditions of digital economy. 2181-1415/C) 2021 in Science LLC.

This is an open access article under the Attribution 4.0 International (CC BY 4.0) license (https://creativecommons.org/licenses/by/4.0/deed.ru)

\footnotetext{
${ }^{1}$ Academician, Professor, Candidate of Economic Sciences, Associate Professor, Fergana Polytechnic Institute. Fergana, Uzbekistan.

E-mail: konstantin@ferpi.uz.
} 


\section{Ўзбекистон иқтисодиётининг саноат тармоқида рақамлаштиришнинг долзарб масалалари}

\author{
Калит сўзлар: \\ саноат сектори, \\ инновация, \\ инновацион жараён, \\ рақобат мухити, \\ рақамли иқтисодиёт, \\ рақамлаштириш.
}

\section{АННОТАЦИЯ}

Мақола муаллифнинг фикрига кўра, билимлар иқтисодиётини яратиш ва муфассал технологияларни жорий қилиш орқали ўлчанадиган иқтисодий натижаларга эришиш учун асос бўлган саноатни рақамли трансформация қилиш мохиятини очиб беришга бағишланган. Саноатни рақамлаштириш минтақавий макон - тармоқ тузилмаларининг технологик ривожланишида мухим рол ўйнайди, шу сабабли саноат ишлаб чиқариш томонидан инновацион рақамли технологияларга асосланган юқори технологияли махсулотларни ишлаб чиқариш мамлакат иқтисодиётини ривожлантириш учун мухим ахамиятга эга.

Муаллиф Ўзбекистон миллий иқтисодиёти саноат тармоғини рақамлаштириш муаммоларини тизимли тахлил қилган. Мақолада муваффақиятли фаолият кўрсатаётган компаниялар мисолида рақамлаштиришнинг самарадорлиги исботланган. Ишлаб чиқаришни рақамли трансформация қилиш махаллий саноат корхоналарининг жахон бозорида самарадорлиги, унумдорлиги ва рақобатбардошлигини оширишга қаратилган бўлиши кераклиги асосланган.

Тадқиқот натижаларига кўра саноат сохасига рақамли иқтисодиёт воситаларини фаол татбиқ этиш зарур деган хулосага келинган.

Тадқиқот натижалари Ўзбекистон иқтисодиётининг саноат секторида рақамлаштириш жараёнларини ривожлантириш ва уларнинг рақамли иқтисодиётдаги рақобатдош устунликларининг ўсишига хизмат қилади хамда минтақавий макон - тармоқ тузилмаларининг технологик ривожланишига йўналтирилганлигини кучайтириш мақсадида фойдаланиш мумкин.

\section{Актуальные вопросы цифровизации в индустриальном секторе экономики Узбекистана}

\footnotetext{
Ключевые слова:

индустриальный сектор, инновации,

инновационный процесс, конкурентная среда, цифровая экономика, цифровизация.
}

\section{АННОТАЦИЯ}

Статья посвящена раскрытию сущности цифровой трансформации промышленности, которая, по мнению автора, является ключом к построению экономики знаний и получению измеримых экономических результатов посредством внедрения сквозных технологий. Цифровизация промышленности играет важную роль в технологическом развитии региональных пространственно-отраслевых структур, поэтому производство промышленностью высокотехнологичной 
продукции на базе инновационных цифровых технологий имеет ключевое значение для развития экономики страны. Автор провел системный анализ проблем цифровизации индустриального сектора национальной экономики Узбекистана. В статье доказывается эффективность цифровизации на примере успешно функционирующих компаний. Обосновано, что цифровая трансформация производства должна быть направлена на повышение эффективности, производительности и конкурентоспособности отечественной промышленности на мировом рынке.

В исследовании сделан вывод о необходимости активного внедрения инструментов цифровой экономики в индустриальном секторе.

Результаты исследования могут быть использованы для развития процессов цифровизации индустриального сектора экономики Узбекистана и усиления их направленности на рост конкурентных преимуществ и технологическое развитие региональных пространственноотраслевых структур в условиях цифровой экономики.

\section{INTRODUCTION}

The beginning of the XXI century have brought the development of digital technologies on the basis of the information revolution and the processes of economic globalization. Information in the society and processes of business management has become the main resource. In the hands of a person, it is transformed into knowledge, and socio-economic relations are increasingly transferred to the network space. The key factor of digital transformation in the performance of market participants is the development of digital culture.

Digital transformation processes are underway all over the world. Taking into account modern realities and trends, Uzbekistan has also begun the transition to a digital economy $[11,16]$. Thus, in 2017, a new version of the Unified Portal of Interactive Public Services was launched, and the National Agency for Project Management under the President of the Republic of Uzbekistan was established. And in 2018, the Digital Trust Fund was established to support the Development of the Digital Economy in order to attract and consolidate investors' funds for the realization of projects in terms of publicprivate partnership, including those related to the introduction of blockchain technology.

Also, the Government Program for the realization of the Action Strategy for the five priority areas of Development of the Republic of Uzbekistan in 2017-2021 in the Year of Development of Science, Education and the digital Economy provides for the realization of large-scale tasks and projects defined by the President in the field of development of the digital economy and e-government $[8,14]$.

For the further development of information technologies, the Presidential Decree "On measures for the widespread introduction of the digital Economy and e-Government" was adopted on April 28, 2020. The document sets out complex measures for the execution of the tasks set. 
A new stage of development in the field was the signing by the President of the Decree "On the approval of the Strategy" Digital Uzbekistan-2030 "and measures for its effective realization" of October 5, 2020. The purpose of the adoption of the document is a successful transition to the digital economy, taking into account modern realities.

The adoption of the Strategy "Digital Uzbekistan-2030" and the "road map" for its implementation in 2020-2022 creates, first of all, the legal basis for the transition to the digital economy. The document includes such priority areas as the development of digital infrastructure, e-government, the national digital technology market, education and advanced training in the field of information technology [11].

The strategy provides for the approval of two programs: digitalization of regions and digitalization of industries. Thus, there are two approaches - territorial and sectoral. Undoubtedly, this will ensure the more complete coverage and effective implementation of the document.

Along with this, ensuring the digitalization of industry today remains one of the most important tasks of the technological development of the economy of Uzbekistan $[1,2,3,4,5,23,24,25]$.

A significant factor stimulating digitalization in various sectors of the economy is the increased availability of modern digital and network technologies, new software, various digital devices and equipment, information and communication technologies based on the Internet and mobile communications [15, 26].

\section{MATERIALS AND METHODS}

In the modern economy, the digitalization of industry is evidenced by the use of new types of equipment, which include: robotic devices, waste-free and unmanned technologies, flexible processing complexes, automatic production facilities, unmanned vehicles, automated technical and technological platforms at various stages of the production process, equipped with digital sensors, sensors, etc. Computer information systems, digital and network technologies, due to the high quality, speed and reliability of transmission, storage and processing of digital signals and other properties, ensure timely decision making aimed at increasing labor productivity, competitiveness, the development of innovations and their introduction in production processes.

According to our deep conviction the digitalization of industry will be developed at an accelerated pace and the main branches of the industrial complex will act not only as the locomotives of technological development of the spatial and industrial structure of the regions, but also as the foundation for the formation of the digital economy of Uzbekistan.

Digitalization in industry is an actual, even fashionable topic today, marking the entry into a new era of industrialization. It provides high flexibility for enterprises in forming business models and broad coverage of the potential customer base by integrating cyber-Physical systems (CPS - Cyber-Physical System) and the Internet of Things (IoT Internet of Things) into the production process. At the heart of the introduction of new technologies is the desire for a complex efficiency improvement and the creation of conditions for the successful operation of the enterprise.

Digitalization of industry is the concept of a new digital space, a united system that integrates production machines, systems for ensuring the life and safety of the enterprise, namely all the electronics of the organization. Gauges and sensors make it possible to combine various physical objects into a virtual network in which they can interact with each other without human intervention. 
The most important advantage of digitalization is to increase the productivity of the company by reducing the time required to develop a new product, release it to the market and deliver it to the consumer, as well as to optimize the resources of the company, which increases the efficiency of its work as a whole.

The modern concept of enterprise digitalization was first introduced in 1996 in the book "Being Digital" by Nicholas Negroponte, who at that time headed the MIT Media Lab. However, in those times was only a matter of theory, only now there is a technical opportunity to put into practice the ideas of a digital enterprise.

In modern conditions, the real need for the digitalization of industrial enterprises is rising, since the problem of processing huge amounts of data that occurs in large manufactures can only be solved by using machines. Modern technologies allow machines not only to perform automatic actions, but also to interact with each other in different fields of activities of the company $[17,21]$.

Summarizing the above, we can say that we are talking not only about the automation of individual stages of production, but also about the introduction of digital technologies in the end-to-end process, which includes not only the production stages, but also related financial and organizational activities. The new approach provides mobility, increases the speed of decision-making and increases the variability of processes depending on the needs of the client.

Digital transformation of the enterprise. As mentioned earlier, for the transition to a digital company or business organization, it is necessary to conduct general digitalization and integration of production and other processes vertically, from product development to production, logistics and in-service maintenance. However, there is also a need for horizontal integration, which goes far beyond one organization and covers both the company itself and its partners, suppliers and customers.

Digital transformation using a variety of modern technologies should be based on an appropriate digital platform. A digital platform is a set of digital data, models and tools that are informationally and technologically integrated into a single automated management system for the targeted subject area, in addition, this platform should organize the interaction of stakeholders among themselves.

It is very important to emphasize that for the transition to the digital form of business, it is necessary to conduct a digital transformation of the organization, which involves the use of the entire pool of modern ICT technologies to dramatically increase the productivity and value of enterprises. Perhaps it is better to say it in another way: a radical increase in the productivity, competitiveness and value of enterprises today is realizable with the parallel digitization of business processes and their fundamental reengineering (BPR, Business Process Reengineering).

If earlier in production only the optimization of its individual phases or stages was considered, today in the framework of digital transformation and the creation of a digital enterprise, an end-to-end process is analyzed, including not only the purely production stages from the idea, development, design, procurement to the manufacture of products, but also related financial activities, personnel work, logistics, operation, support, partner network, subcontractors, etc. After all, the main goals of digital transformation are to increase the speed of decision-making, increase the variability of processes depending on the needs and preferences of the client, and reduce the number of employees involved in the process (that is, decision-making and value creation chains). In general, sociality, 
mobility, analytics and "clouds" are the foundation on which a digital enterprise is built. And it is quite logical that this results in a potentially higher level of labor productivity, collaboration, cooperation, control, support, and, accordingly, the predictability of the result of work. And the time and cost of launching new products sometimes decrease significantly. All this is done in the name of radically increasing the profit, competitiveness and market value of the enterprise. And if you do not see what exactly can seriously improve the competitiveness of the enterprise, then the question of payback or targeted use of investments in digital transformation immediately arises. This issue will be especially important for monopolies $[9,10,11]$.

A digital enterprise involves digitalizing and integrating processes vertically across the entire manufacture from product development and procurement to manufacturing, logistics, and in-service maintenance. In turn, the horizontal integration of the digital enterprise extends beyond internal operations to include suppliers, consumers, and all key partners across the entire value chain. It uses a variety of technologies, from tracking and monitoring devices to integrated planning integrated with real-time execution. All this is done on the basis of the corresponding digital platform and all together makes up the socalled digital ecosystem of the digital enterprise.

Summarizing all of the above, a radical increase in the volume of production and the value of the enterprise, as well as its competitiveness in the market, is possible only under the condition of a comprehensive digital transformation of all business processes.

Goals and objectives of digitalization. Previously, the optimization of production involved the modernization of its individual elements and stages. Digitalization is the transformation of an ordinary enterprise into a digital one, it can be considered as a global process that includes updating not only all production stages, but also all related activities of the company:

* Personnel Policy;

* Logistics;

- Financial activities;

- Operation of production areas.

Based on the general concept of digitalization, its goal is to increase the speed of decision-making in production, to increase the variability of production processes, and to reduce the number of employees involved in the work.

When the goals are achieved through digital transformation, a higher level of productivity, cooperation, collaboration, quality control, support and predictability of production results is achieved.

This makes it possible to dramatically increase the profit, competitiveness and overall market value of the enterprise.

Analysis of the main directions of digitalization of an industrial enterprise. Digital transformation is currently being implemented in almost all areas of industry, including the digitalization of mining, mechanical engineering, aviation, space, energy, food processing, and many others. As part of this process, active work is necessarily carried out with the Internet of Things, or in this case with the "Industrial Internet of Things" (IIoT).

Often, the information passes by the human operator, which reduces the likelihood of abnormal and emergency situations due to the human factor. 
Of course, digitalization in industry and in other areas of production is not only a huge opportunity for development and increasing profits, but also serious risks, since a failure in a single system can cost much more than standard failures and accidents. Therefore, software and technical solutions for creating a modern digital enterprise are subject to increased requirements $[12,13]$.

At the same time, there are several main directions in the process of digitalization of an industrial enterprise:

* Accelerate the introduction of new products to the market;

- Improving the safety and reliability of production;

* Increase production flexibility;

* Improving the quality of manufactured goods;

* Overall increase in production efficiency.

* A full-fledged transformation of the enterprise into a digital one involves carrying out work in all these areas.

Digitalization of an industrial enterprise. Before digitalizing companies, it is necessary to conduct comprehensive research beforehand, which will allow you to know in advance how modern concepts and technologies can affect their business. It is necessary to have accurate data on the capacity and capabilities, the general state of the target enterprise, in order to correctly set the goals of digital transformation and achieve a positive result in the end.

To draw up a program for the digitalization of industry, you must first answer the following questions:

I. What can digitalization give?

II. What are its goals for the enterprise?

III. At what stage of digital transformation is the organization currently at, which of the technologies used can be preserved?

IV. What digitalization work can the company perform on its own, and which will require the help of specialists?

Subsequently, the list of questions expands, and there is a need to choose the appropriate tools, software and technical solutions. However, at the first stage, it is necessary to decide whether such a transformation can currently lead to positive results for the company or not and how such transition economically justified will be.

What does digitalization bring? The benefits of digital transformation are best seen in examples. One of the most successful projects implemented to date can be considered a project of the company Siemens, where not only develop, but also implement smart systems.

The corporation has launched an electronics factory in Amberg which specializes in the production of industrial controllers. The company produces more than 1,000 products with a volume of about $12,000,000$ controllers annually. More than $75 \%$ of all work performed is carried out by works and automated machines, production is integrated with the design subsystem - design systems transmit all the necessary data about technological processes directly to production. The codes applied to the models inform the equipment about the technological route and the requirements for each operation performed. This technology allows you to achieve a product quality indicator at the factory at the level of 99.999\%. 
Every day, more than 50 million records of a production and technical nature are created in production, which can be used to analyze the entire life cycle of manufactured products.

By introducing IoT in production, companies want to convert the benefits of "Industry 4.0" technologies into clear business indicators. For example, the manufacturer of machine tools, the Japanese corporation FANUC, reduced equipment downtime and thus received $\$ 40$ million more revenue for the year. In the production of Stanley and Black tools \& Decker after the introduction of IoT, the number of defects and marking errors decreased by $16 \%$. And Singapore-based electronics manufacturer Flextronics has reduced energy consumption at its factories by $20 \%$.

If we talk about global cases, one of the most striking examples is the Chrysler plant in Toledo, which produces more than 700 car bodies every day. At the same time, 259 German KUKA robots are involved, which "communicate" with 60,000 other devices and machines. And all this data exchange and storage is organized in a cloud environment. As a result, the productivity and flexibility of such a plant is significantly increased, not to mention the efficiency of process management.

In the field of digitalization, Uzbekistan is still inferior in the development and dissemination of technologies to many Western and Asian countries, but we are also working in this direction in the most active way. Already, many industrial companies are optimizing their business models and production through digital transformation. Examples include JSC "UzAutoMotors", SamAuto, Navoi Mining and Metallurgical Combine, Almalyk Mining and Metallurgical Combine, British Tobacco Company Uzbekistan, Artel Group of Companies and others.

Digitalization is becoming increasingly widespread in such a well-regulated and regulated area as industrial safety, since the issues of labor protection and employee health are a priority and relevant for any company. Innovations are designed not so much to eliminate the consequences of the events that have occurred, as to prevent their occurrence in advance, to act proactively $[19,20,26,27]$. This is due to the introduction of new production methods and digital solutions that contribute to the growth of production efficiency; to reduce the number of cases of occupational injuries and deviations in the state of health of personnel; to increase the level of accident-free and safe production.

Digital technologies, for example, are able to detect industrial incidents that previously could not be identified - this is a violation of the regime of being in dangerous or closed areas by employees or the lack of personal protective equipment. Moreover, the "digital" information about the activity of people at specific production stages, as well as the automatically measured duration of operations, received in real time, allows you to create a digital model of the working day of all employees and analyze the processes in the enterprise on the basis of this information.

Actual problems of digitalization of the industrial sector of the national economy of Uzbekistan.

The opportunities and benefits of digitalization are rarely questioned, including in our country, but the World Bank's research shows that Uzbekistan lags behind Western countries in terms of digitalization by more than a decade.

This is evidenced by the statistics:

1. The share of the digital economy in the GDP of Uzbekistan is about $2.2 \%$, in countries with developed market economies - 16-35\%. 
2. The number of innovative industrial enterprises in Uzbekistan is less than 5\%, in some EU countries - up to $60 \%$.

3. The number of people employed in high-tech / knowledge-intensive industries in Uzbekistan - 0.5\%, in Western countries - 6\%

Our research has shown several reasons for Uzbekistan's lagging behind the leading countries in the field of digitalization:

1. Economic instability, exacerbated by the effects of the pandemic. There are few manufacturers of high-quality hardware in the country: processors, sensors, modems, etc., and foreign products are expensive and sometimes simply unavailable for the domestic market $[3,18,22,28]$.

2. Lack of clear standards. For the effective development of the high-tech market, it is necessary to have standards in the field of IoT, which are only beginning to appear in the domestic legislation. Individual processes are not at all structured at the state level, which greatly hinders the introduction of digital technologies.

3. Lack of qualified specialists

The country's educational system lags behind the development of the digital technology market and does not have time to provide interested companies with highquality personnel $[5,9,15]$.

4. The desire of the business to make a quick profit

Many domestic companies are interested only in the most liquid projects, which in the short term will be able to bring a large income. In Western countries, corporations are happy to invest billions of dollars in projects with a payback period of 30 years; in our country, companies try to invest only in those technologies that will pay off in two years. Therefore, digitalization is generally less attractive for domestic businesses.

Unfortunately, many enterprises cannot yet realize the full potential of digitalization and the possibilities of switching to new technologies $[6,7,10]$.

\section{CONCLUSION}

Today, the enterprises of the industrial sector of Uzbekistan face new and sometimes frightening questions that must be answered in the process of "digitalization":

Who in my organization initiates the digital transformation?

* What can we achieve?

* What are the goals?

Is digitizing everything a digital project or something more?

Where to start?

* Who is responsible for conceptualization and performance?

Where are we today in terms of opportunities?

What can we do ourselves, and why do we need to hire specialists?

How to ensure the flexibility of large ecosystems?

How can I take advantage of the technological evolution associated with layers of technical architectures?

Each industrial manufacturing organization must go through this introspective project to determine the business goals and the main tools to achieve them. This will allow you to remain relevant and successful in a changing environment. Then the organization 
must connect its current state of "ready for flexibility" with targeted state by this process. Readiness is then determined by assessing the maturity of the enterprise in key areas, and transformation guidelines are set. These key areas can be identified using key elements of the business value chain, such as:

* Product lifecycle management.

* Production and product management.

* Business analytics.

* "Integration" and data management.

Security.

* Corporate culture and the people behind it.

* Measurement of processes and technologies.

This process allows you to connect digital transformation with the overall strategy of the enterprise, as it relates to the main business indicators. It also helps to justify current and capital costs in the context of digital transformation. This allows you to evaluate any activity in the perspective of the long-term goals of the "digitized" organization.

The digital transformation project is best complemented by the use of the "digital maturity model", as a basis for determining the current state and desired state, in terms of the main areas key to a sustainable business.

Thus, the successful implementation of the digitalization of the industrial sector of the economy will contribute not only to the transition to the digital economy, taking into account modern realities, but also to improving the position of Uzbekistan in the relevant world indices and ratings, as well as strengthening the country's image in the international arena. Digital technologies are evolving so rapidly that the legal framework needs to be constantly monitored to ensure that it remains relevant to technological developments. Also, in the future, it is necessary to solve the issues of cybersecurity of industrial systems. Data protection should be an important principle for encouraging enterprises to innovate and develop new ideas, methods and technologies for the security and protection of personal data.

\section{REFERENCES:}

1. Kagermann H. (2015). Change through digitization - Value creation in the age of Industry 4.0. In Management of permanent change (PP. 23-45). Springer Gabler, Wiesbaden.

2. Abdullaev A.M., \& ets. (2019). Actual issues of activization of financial factors development of entrepreneurship in Uzbekistan. Kazakhstan Science Journal,2(3), 49-58.

3. Ashurov M.S., and ets. (2020). Entrepreneurship and directions of its development in the context of the COVID-19 pandemic: theory and practice. GlobeEdit Academic Publishing.

4. Doi: https://doi.org/10.5281/zenodo.4046090.

5. Zangiacomi A., Pessot E., Fornasiero R., Bertetti M., \& Sacco M. (2020). Moving towards digitalization: a multiple case study in manufacturing. Production Planning \& Control, 31(2-3). - PP. 143-157.

6. Ashurov M. S. and ets. (2019). O‘zbekistonda tadbirkorlik muhitining zamonaviy holati va uni samarali rivojlantirish muammolarini baholash. GlobeEdit Academic Publishing.

7. Doi: http://dx.doi.org/10.13140/RG.2.2.34273.74088 
8. Korovin G.B. (2018). Problems of industrial digitalisation in Russia. Journal of new economy, 19(3). Bessière D., Charnley F., Tiwari A., \& Moreno M.A. (2019). A vision of re-distributed manufacturing for the UK's consumer goods industry. Production Planning \& Control, 30(7). - PP. 555-567.

9. Gbadegeshin S.A. (2019). The effect of digitalization on the commercialization process of high-Technology companies in the life sciences industry. Technology Innovation Management Review, 9(1).

10. Fitzgerald M., Kruschwitz N., Bonnet D., \& Welch M. (2014). Embracing digital technology: A new strategic imperative. MIT sloan management review, 55(2), 1.

11. Frank A.G., Mendes G.H., Ayala N.F., \& Ghezzi A. (2019). Servitization and Industry 4.0 convergence in the digital transformation of product firms: A business model innovation perspective. Technological Forecasting and Social Change. - P. 141, - PP. 341-351.

12. lyosov, A. A., and ets. (2020). Problems of the use of digital technologies in industry in the context of increasing the export potential of the country. ISJ Theoretical \& Applied Science, 10 (90). - PP. 113-117.

13. Doi: https://dx.doi.org/10.15863/TAS.2020.10.90.23

14. Ivanov D., Dolgui A., \& Sokolov B. (2019). The impact of digital technology and Industry 4.0 on the ripple effect and supply chain risk analytics. International Journal of Production Research, 57(3). - PP. 829-846.

15. Ivanovich K.K. (2020). About some questions of classification of institutional conditions determining the structure of doing business in Uzbekistan. South Asian Journal of Marketing \& Management Research, 10(5). - PP. 17-28.

16. Doi: https://doi.org/10.5958/2249-877X.2020.00029.6.

17. Khotamov I., Khujanazarova N., Nosirova G.G., \& Nazarova G. (2019). world tendencies of development of the digital economy and insurance in Uzbekistan. Мамлакат иқтисодий хавфсизлигини таъминлашнинг устувор йўналишлари, 7-7.

18. Sternick S.A. (2020). Digital governance and digital economy in Uzbekistan. Global Crossroads: Rethinking Dominant Orders in Our Contested World. - P. 133.

19. Kambarov I., D’antonio, G., Aliev, K., Chiabert, P., \& Inoyatkhodjaev, J. (2018, July). Uzbekistan towards industry 4.0. defining the gaps between current manufacturing systems and industry 4.0. In IFIP International Conference on Product Lifecycle Management (PP. 250-260). Springer, Cham.

20. Parviainen P., Tihinen M., Kääriäinen J., \& Teppola S. (2017). Tackling the digitalization challenge: how to benefit from digitalization in practice. International journal of information systems and project management, 5(1). - PP. 63-77.

21. Kurpayanidi K.I. (2020). To the problem of doing business in the conditions of the digital economy. ISJ Theoretical \& Applied Science, 09 (89), 1-7. Doi: https://dx.doi.org/10.15863/TAS.2020.09.89.1.

22. Kurpayanidi K.I. (2020). On the problem of macroeconomic analysis and forecasting of the economy. ISJ Theoretical \& Applied Science, 03 (83). - PP. 1-6.

23. Doi: https://dx.doi.org/10.15863/TAS.2020.03.83.1.

24. Hirsch-Kreinsen, H. (2016). Digitization of industrial work: development paths and prospects. Journal for Labour Market Research, 49(1). - PP. 1-14. 
25. Babkin A.V., Burkaltseva D.D., Betskov A.V., Kilyaskhanov H.S., Tyulin A.S., \& Kurianova I.V. (2018). Automation digitalization blockchain: trends and implementation problems. International Journal of Engineering and Technology (UAE), 7 (3.14 Special Issue 14). - PP. 254-260.

26. Vishnyakova A.B., Bondarenko D.A., \& Agisheva M.A. (2021). Actual Problems of Industry Digitalization in Russia. In Current Achievements, Challenges and Digital Chances of Knowledge Based Economy (pp. 431-439). Springer, Cham.

27. Ziyadin S., Litvishko O., Dubrova M., Smagulova G., \& Suyunchaliyeva M. (2019). Diversification tourism in the conditions of the digitalization. International Journal of Civil Engineering and Technology, 10(2). - PP. 1055-1070.

28. Mamatova Z.M., Nishonov F.M. end ets. (2019). To the question of Science approach to the construction of outsourcing business model of modern enterprise structure. Dostijeniya nauki I obrazovaniya. 7 (48). URL: https://cyberleninka.ru/ article/n/ to-the-question-of-science-approach-to-the-construction-of-outsourcingbusiness-model-of-modern-enterprise-structure

29. Felser K., \& Wynn M.G. (2020, March). Digitalization and IT Backsourcing: Towards a Transformational Model for the German Automobile Industry. In eKNOW 2020: The Twelfth International Conference on Information, Process, and Knowledge Management (PP. 7-16). IARIA.

30. Margianti E.S., Ikramov M.A., Abdullaev A.M., (2020). Role of goal orientation as a predictor of social capital: Practical suggestions for the development of team cohesiveness in SME's. Monograph. Gunadarma Pulisher, Indonesia. Doi: http://dx.doi.org/10.13140/RG.2.2.28953.44641.

31. Motyl B., Baronio G., Uberti S., Speranza D., \& Filippi S. (2017). How will change the future engineers' skills in the Industry 4.0 framework? A questionnaire survey. Procedia Manufacturing, 11, 1501-1509.

32. Tkach D.V. and ets. (2020). Some questions about the impact of the COVID-19 pandemic on the development of business entities. ISJ Theoretical \& Applied Science, 11 (91), 1-4. Doi: https://dx.doi.org/10.15863/TAS.2020.11.91.1. 